\title{
Petroleum Geology of Outcropping Sediments along Imiegba Road in Etsako East Local Government Area of Edo State, Southern Anambra Basin Flank, Nigeria: Inference from Sedimentology and Organic Geochemistry
}

\author{
A. N. Asadu ${ }^{1^{*}}$ and K. A. Ibe ${ }^{2}$ \\ ${ }^{1}$ Department of Earth Sciences, Federal University of Petroleum Resources, Effurun, Delta State, \\ Nigeria. \\ ${ }^{2}$ Department of Chemistry, Federal University of Petroleum Resources, Effurun, Delta State, Nigeria.
}

Authors' contributions

This work was carried out in collaboration between both authors. Author ANA designed the study, performed the statistical analysis, wrote the protocol and wrote the first draft of the manuscript. Author KAl managed the analyses of the study and the literature searches. Both authors read and approved the final manuscript.

Article Information

DOI: 10.9734/JGEESI/2017/33891

Editor(s):

(1) Anthony R. Lupo, Department of Soil, Environmental and Atmospheric Science, University of Missouri, Columbia, USA.

Reviewers:

(1) Fehmi Arikan, General Directorate of Mineral Research and Exploration, Ankara, Turkey.

(2) Kadiri Umar Afegbua, Centre for Geodesy and Geodynamics, Nigeria. Complete Peer review History: http://www.sciencedomain.org/review-history/19591

Original Research Article

Received $2^{\text {nd }}$ May 2017

Accepted $19^{\text {th }}$ May 2017

Published $17^{\text {th }}$ June 2017

\begin{abstract}
The outcropping sediments along Imiegba road have been studied using their sedimentological and organic geochemical (Total organic carbon, TOC and Soluble organic matter, SOM) parameters. A total of sixteen (16) samples were collected and analyzed for the study. Based on sedimentological and field evidences, the main lithofacies identified from the study area are sandstone, shale and claystone. The sandstones are fine to medium-grained and friable. Also the result of the textural analyses show that the sandstones are sub-rounded, moderately to poorly sorted, strongly coarsely skewed and mesokurtic. The calculated permeability values ranging from 307.18-724.85 Md showed
\end{abstract}


that they possess good permeability. Based on the high permeability values of the sands, the sandstones were inferred as good to excellent potentials for fluid transmission making them good reservoir for hydrocarbon.

The TOC values range from $0.17-1.42 \mathrm{wt} .(\%)$ with most of the samples above the threshold of 0.5 wt.\% while the SOM, greater than $500 \mathrm{ppm}$ indicates that the shales have poor to good organic matter quantity and in adequate concentration for petroleum generation if other factors are suitable.

Keywords: Geochemistry; permeability; porosity; sedimentology; sandstone; shale; reservoir.

\section{INTRODUCTION}

The studied area "Imiegba" is located in Etsako East local Government area of Edo state, Benin flank of the southern Anambra Basin, Nigeria and falls within the co-ordinates $\mathrm{N} 07^{0} 11^{1} 27.0^{11}$ and E006 ${ }^{0} 26^{1} 48^{11}$ (Fig. 1). This study was aimed at the determination of the hydrocarbon potentials as well as the reservoir quality of the outcropping sediments along Imiegba road using Sedimentological, and Organic Geochemical analysis. The objectives of the study were to determine the lithofacies characteristics of the sediments of the study area, the hydrocarbon potential from geochemical parameters such as TOC and SOM, and characterize the reservoir properties (porosity and permeability) from the textural analysis.

\section{GEOLOGIC SETTING STRATIGRAPHY}

The Anambra Basin is one of the Cretaceous sedimentary basins of Nigeria, bounded on the south-western flank by the Niger Delta hinge line, northwest by the Benue flank and southeast by the Abakaliki fold belt. The basin is roughly triangular in shape and covers an area of about 40,000 square kilometres with sediment thickness increasing southwards to a maximum thickness of $12,000 \mathrm{~m}$ in the central part of Niger Delta [2]. The basin lies between latitudes $5.00 \mathrm{~N}$ and $8.00 \mathrm{~N}$ and longitudes $6.30 \mathrm{E}$ and $8.00 \mathrm{E}$. Anambra Basin is one of the intracratonic basins in Nigeria and its origin is linked to the tectonic processes that accompanied the separation of the African and South American plates in the Early Cretaceous during the opening of the Atlantic [3,4],(Fig. 2).

Anambra Basin is a post Santonian depo-centre in Southern Nigeria. Before the Santonian tectonism, Anambra Basin and Afikpo syncline were platforms bordering the Benue trough to the west and east respectively [2]. The compressional stress regime that dominated during the Santonian period, led to the folding and uplift of the Abakaliki sector of the Benue Trough [5]. Consequently the bordering platforms

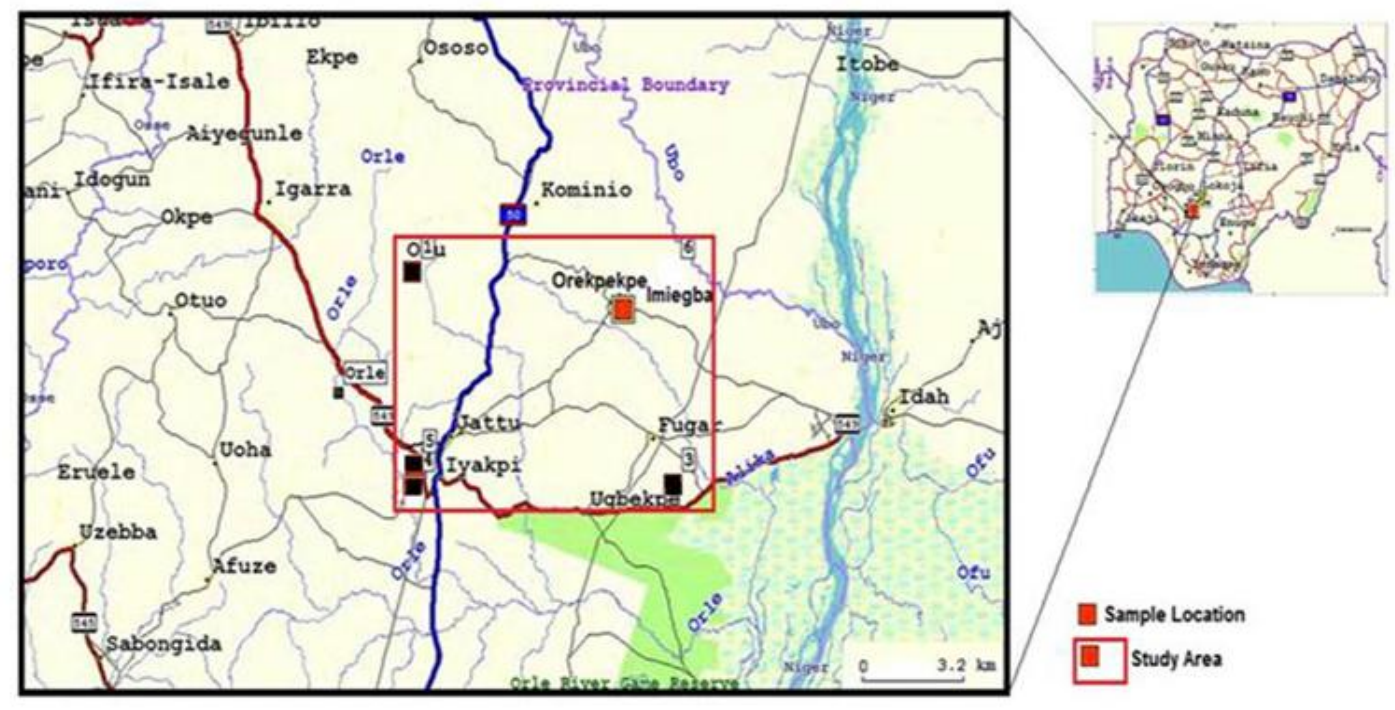

Fig 1. Location map of the studied area [1] 
were downwarped to form Anambra Basin and Afikpo syncline, [6] and [3]. Sediments were sourced from the Abakaliki anticlinorium to these basins with subsequent accumulation of thick sedimentary pile ranging from late Cretaceous Tertiary in age. The earliest sedimentation episode in Anambra Basin was the Campano Maastrichtian sedimentation cycle that led to the deposition of Nkporo Shale with Enugu Shale as its lateral equivalent. This unit is overlain by the Mamu Formation (Lower Coal Measures), which is conformably overlain by Ajali sandstone. The Nsukka Formation overlies the Ajali sandstone. it is characterized by alternating succession of sandstones, mudstones, dark shales and sandy shales with thin coal seams at some horizons (the upper Coal Measures) $[7,8]$. This Formation ranges from late Maastrichtian to Danian in age, [9].

The Tertiary succession consists of the Paleocene Imo Shale which conformably overlies the Nsukka Formation. This formation is composed predominantly of thick fossilferous clayey shales. It is overlain by the Ameki Formation of Eocene age characterized by greys-green sandy clays, sandstones and claystones with calcareous concretions, clayey sandstones with occasional shelly lime stones and lignites at some horizons. The Stratigraphic summary is given in Table1.

\section{METHOD OF STUDY}

This research involved the Field Mapping (logging of outcrop) and sample collection of outcropping sediments in the study area, laboratory studies involving sedimentological, Total Organic Carbon (TOC and SOM) analyses of collected samples, quantitative determination of permeability of the sediments, and subsequent interpretation of the results.

\subsection{Sample Collection}

A total of sixteen (16) fresh samples were collected from the outcrop section for this study. Samples were taken from fresh, unweathered surfaces to be able to reveal the original, unaltered structural and mineralogical (chemical) properties of the rocks. The samples were kept in sample bags (polythene bags) and later taken to laboratory for analyses.

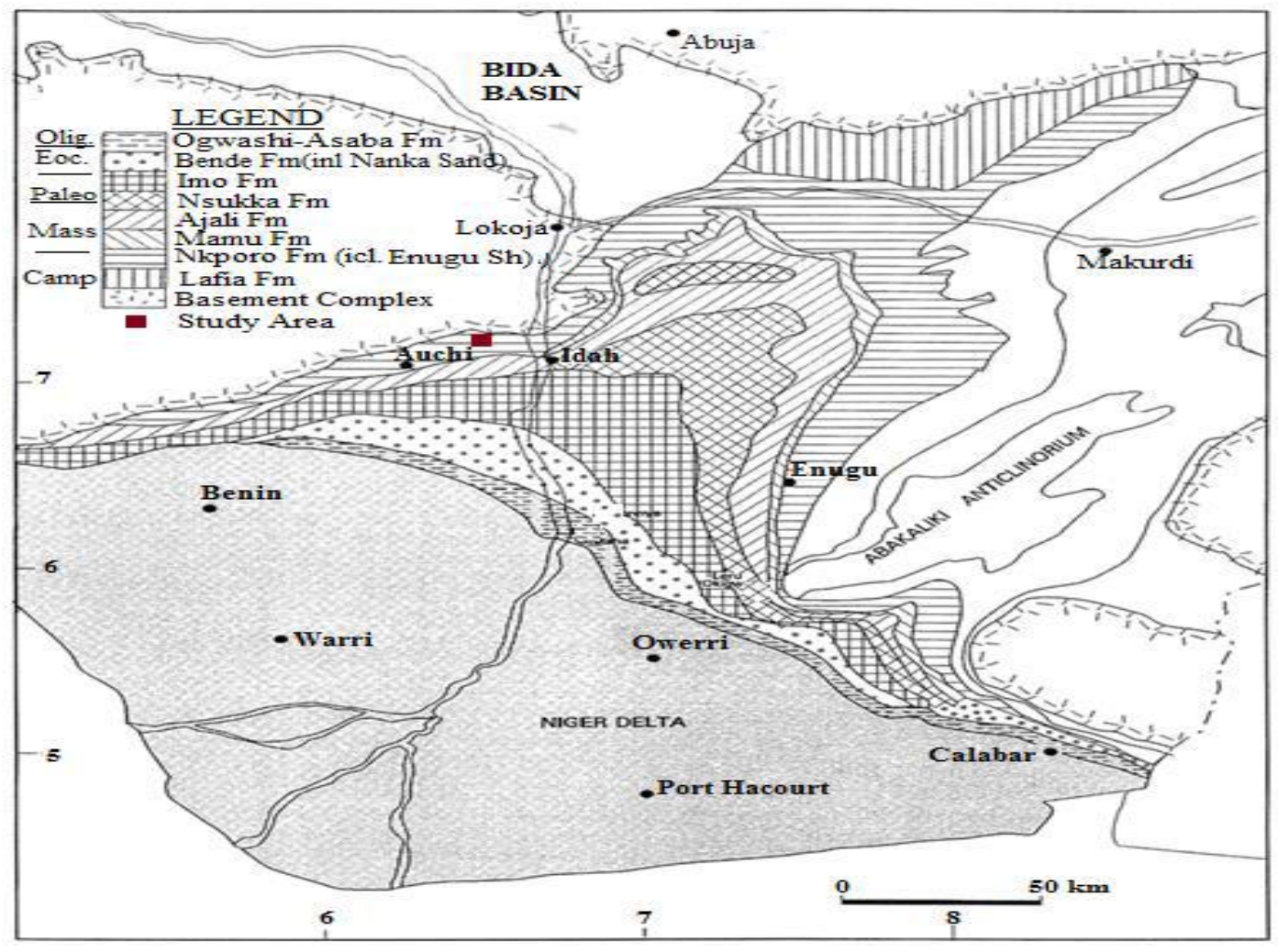

Fig. 2. Geological map of Anambra Basin modified from [1] 
Table 1. Stratigraphic sequences in the Anambra Basin (Modified from [7])

\begin{tabular}{|c|c|c|c|c|c|c|c|c|}
\hline Age & Basin & \multicolumn{7}{|c|}{ Stratigraphic units } \\
\hline Thanetian & Niger & Imo format & & & & & & \\
\hline Maastrichtian & $\begin{array}{l}\text { Anambra } \\
\text { Basin }\end{array}$ & $\begin{array}{l}\text { Coal } \\
\text { Measures }\end{array}$ & $\begin{array}{l}\text { Nsukka } \\
\text { Ajali for } \\
\text { Mamu f }\end{array}$ & $\begin{array}{l}\text { ormation } \\
\text { ation } \\
\text { mation }\end{array}$ & & & & \\
\hline Campanian & & $\begin{array}{l}\text { Nkporo } \\
\text { Fm }\end{array}$ & $\begin{array}{l}\text { Nkporo } \\
\text { Shale }\end{array}$ & $\begin{array}{l}\text { Enugu } \\
\text { Fm }\end{array}$ & $\begin{array}{l}\text { Owelli } \\
\text { Sst }\end{array}$ & $\begin{array}{l}\text { Afikpo } \\
\text { Sst }\end{array}$ & $\begin{array}{l}\text { Otobi } \\
\text { Sst }\end{array}$ & $\begin{array}{l}\text { Lafia } \\
\text { Sst }\end{array}$ \\
\hline Santonian & $\begin{array}{l}\text { Southern } \\
\text { Benue } \\
\text { Trough }\end{array}$ & Awgu Form & tion & & & & & \\
\hline
\end{tabular}

\subsection{Textural Analysis}

The samples were subjected to sieve analysis to determine the grain size distribution, sorting, kurtosis and skewness. Quantitative determination of permeability was also done using the data set from sieve analysis. Values obtained were used to plot a graph of Cumulative Weight Percent (\%) versus Phi ( $\varnothing)$ from where statistical moments were determined. The statistical moments (parameters) of [10] were used for the Granulometric analysis as follows.

$$
\begin{aligned}
& \text { Mean }(\mathrm{Mz})=\frac{\phi 16+\phi 50+\phi 84}{3} \\
& \text { Sorting/Standard Deviation }(\delta \mathrm{I})= \\
& \frac{\phi 84-\phi 16}{4}+\frac{\phi 95-\phi 5}{6.0} \\
& \text { Graphic Skewness (SKI) }= \\
& \frac{\phi 16+\phi 84-2 \phi 50}{2(\phi 84-\phi 16)}+\frac{\phi 5+\phi 95-2 \phi 50}{2(\phi 95-\phi 5)} \\
& \text { Graphic Kurtosis (KG) }=\frac{\phi 95-\phi 5}{2.44(\phi 75-\phi 25)}
\end{aligned}
$$

The foregoing parameters of [10] were then used to determine the paleodepositional environment for the sediments using the plot model of [11].

\subsection{Quantitative Determination Permeability}

Quantitative determination of permeability was done using the empirical formula propounded by [12] as follows.

$\mathrm{K}=\mathrm{CODm} 2 \mathrm{e}-1.31 \delta$

Where;

$$
\mathrm{K}=\text { permeability in millidarcies }(\mathrm{mD})
$$

$$
\begin{aligned}
& \mathrm{CO}=\text { empirical constant }(769 \text { Darcies } / \mathrm{mm} 2) \\
& \mathrm{Dm}=\text { median diameter }(\mathrm{mm}) \\
& \delta=\text { sorting }(\text { Phi standard deviation })
\end{aligned}
$$

\subsection{Total Organic Matter Analysis Procedure}

$2.0 \mathrm{~g}$ of the samples were weighed into $250 \mathrm{ml}$ conical flask [Erlenmeyer]; and $10 \mathrm{ml}$ of $1 \mathrm{~N}$ $\mathrm{K}_{2} \mathrm{Cr}_{2} \mathrm{O}_{7}$ solution was accurately pipetted into each flask and swirled gently. $20 \mathrm{ml}$ conc. $\mathrm{H}_{2} \mathrm{SO}_{4}$ was added rapidly and swirled; allowed to stand for 30 minutes after which $100 \mathrm{ml}$ of distilled water were added. $10 \mathrm{ml}$ of O-phosphoric acid was added with 3-4 drops of diphenylamine indicator and titrated with $0.5 \mathrm{~N}$ ferrous ammonium sulphate till the colour changed from green to blue and finally to green colour which is the end point. The blank titration was also set up in the same manner but without the sediment $[3,4,5,6]$ to standardize the dichromate.

The TOC was calculated according to the following formula.

$\%$ TOC $=\left(\mathrm{ml} \mathrm{Fe}^{2+}\right.$ for blank $-\mathrm{ml} \mathrm{Fe} e^{2+}$ for sample / Wt of sediment in gram (g)) $\mathrm{x}$ Normality of $\mathrm{Fe}^{2+*} 0.390$ sample

\subsection{Soluble Organic Matter Analysis Procedure}

$30 \mathrm{~g}$ of the sieved outcrop sample was placed inside a thimble and placed inside the soxhlet extractor. The thimble was pre-extracted with hexane-acetone $(1: 1 \mathrm{v} / \mathrm{v})$ before placing the sample in it. The sample was then extracted with same solvent mixture for 10 hours.

The extracts were cleaned by passing them through a column of anhydrous sodium tetraoxosulphate (vi). 


\section{RESULTS AND DISCUSSION}

\subsection{Sedimentology}

Based on field study, four (4) lithofaciessandstone, siltstone, claystone and shales were encountered in the studied location (Fig. 3). The Percentile Values for the Granulometric Analysis are presented in Table 2, and the Graphical Representation of the percentiles are shown in Fig. 4, while the summary of the textural attributes of the sediments interpreted from the sieve analysis results are given in Table 3.

\subsection{Petrophysical Analysis}

Porosity is highly dependent on sediment sorting and grain packing [13]. Poorly sorted sediments usually have low porosity. The finer sediments in poorly sorted sediments typically fill the pore spaces thereby impeding porosity. Similarly, permeability is a secondary property of rocks and depends on its primary properties such as texture, composition and structure. In particular, permeability depends on parameters such as grain size, shape and size of pores (porosity), sorting, packing and/or compaction.

From the calculated sorting values (Table 3) which generally indicate moderate to poor sorting, a moderate to poor porosity was inferred for the sediments. However, the sandstones as observed from the outcrops were mainly friable to moderately-consolidated. It is therefore, inferred that porosity-loss in the sediments for this study due to compaction has been minimal. This inference is based on the fact that porosity reduces with compaction. Empirical determination of permeability using [11] formula for the sand facies of the study area shows that the sediments have good permeability (Table 4). The application of the empirical formula of [11] is premised on the fact that there is a valid relationship between porosity and permeability in sandstones. The high permeability values are due to the poor to moderate consolidation of the sediments as well as the sub-rounded morphology of most of the grains.

Table 2. Percentile values from the granulometric analysis

\begin{tabular}{lllllllll}
\hline S/N & Sample Intervals & $\mathbf{5 \%}$ & $\mathbf{1 6 \%}$ & $\mathbf{2 5 \%}$ & $\mathbf{5 0 \%}$ & $\mathbf{7 5 \%}$ & $\mathbf{8 4 \%}$ & $\mathbf{9 5 \%}$ \\
\hline 1 & BED 3 & 1.55 & 0.8 & 1.74 & 2.0 & 2.9 & 3.17 & 3.8 \\
2 & BED 5 & 0.15 & 1 & 1.3 & 1.9 & 2.18 & 3.18 & 3.7 \\
3 & BED 6 & 0.03 & 0.51 & 0.78 & 1.34 & 1.73 & 1.94 & 3.6 \\
4 & BED 7 & -1.1 & -0.2 & 0.5 & 2.24 & 3.18 & 3.3 & 3.7 \\
5 & BED 13 & -1.4 & -0.6 & -0.1 & 1.6 & 2.9 & 3.34 & 4.2 \\
6 & BED 15 & 1.24 & 1.6 & 1.8 & 2.14 & 2.54 & 2.9 & 4.0 \\
\hline
\end{tabular}

Table 3. Textural interpretation of the sediments

\begin{tabular}{|c|c|c|c|c|c|c|}
\hline Bed & Median & Mean & Sorting & Skewness & Kurtosis & Interpretation \\
\hline 1 & 2.0 & 1.99 & 0.955 & 0.290 & 0.77 & $\begin{array}{l}\text { Medium grained, moderately well } \\
\text { sorted, strongly fine-skewed, and } \\
\text { platykurtic. }\end{array}$ \\
\hline 3 & 1.9 & 2.03 & 1.14 & 0.094 & 0.92 & $\begin{array}{l}\text { Fine grained, poorly sorted, strongly } \\
\text { fine skewed, mesokurtic. }\end{array}$ \\
\hline 5 & 2.24 & 1.78 & 1.675 & -0.393 & 0.73 & $\begin{array}{l}\text { Medium grained, poorly sorted, } \\
\text { strongly fine skewed, platykurtic. }\end{array}$ \\
\hline 6 & 1.6 & 1.45 & 1.915 & -0.094 & 1.03 & $\begin{array}{l}\text { Medium grained, poorly sorted, } \\
\text { strongly coarse-skewed, platykurtic }\end{array}$ \\
\hline 7 & 2.14 & 2.21 & 0.785 & 0.418 & 0.95 & $\begin{array}{l}\text { Fine grained, moderately sorted, } \\
\text { strongly fine-skewed, mesokurtic. }\end{array}$ \\
\hline 13 & 1.66 & 1.66 & 0.45 & 0.02 & 0.9 & $\begin{array}{l}\text { Medium grained, moderately } \\
\text { sorted, strongly coarse skewed, } \\
\text { platykurtic. }\end{array}$ \\
\hline 15 & 2.59 & 2.6 & 0.683 & 0.08 & 0.94 & $\begin{array}{l}\text { Fine grained, poorly sorted, strongly } \\
\text { fine skewed, mesokurtic. }\end{array}$ \\
\hline
\end{tabular}




\begin{tabular}{|l|l|l|}
\hline DEPTH(FT) \\
LITHOOLOGY
\end{tabular}

Fig. 3. Litholog of the studied area

From the above interpretations (Table 3 ), the sandstone facies are fine to medium- grained, sub-angular to sub-rounded, moderately to poorly sorted sands with the sorting values ranging from $0.67-1.92$. The sediments are strongly coarse, skewed and ranges from mesokurtic to leptokurtic. It also showed that the porosity and permeability of the sandstone facies of the study outcrop is high, which indicates a good reservoir quality. 
Asadu and Ibe; JGEESI, 10(3): 1-10, 2017; Article no.JGEESI.33891
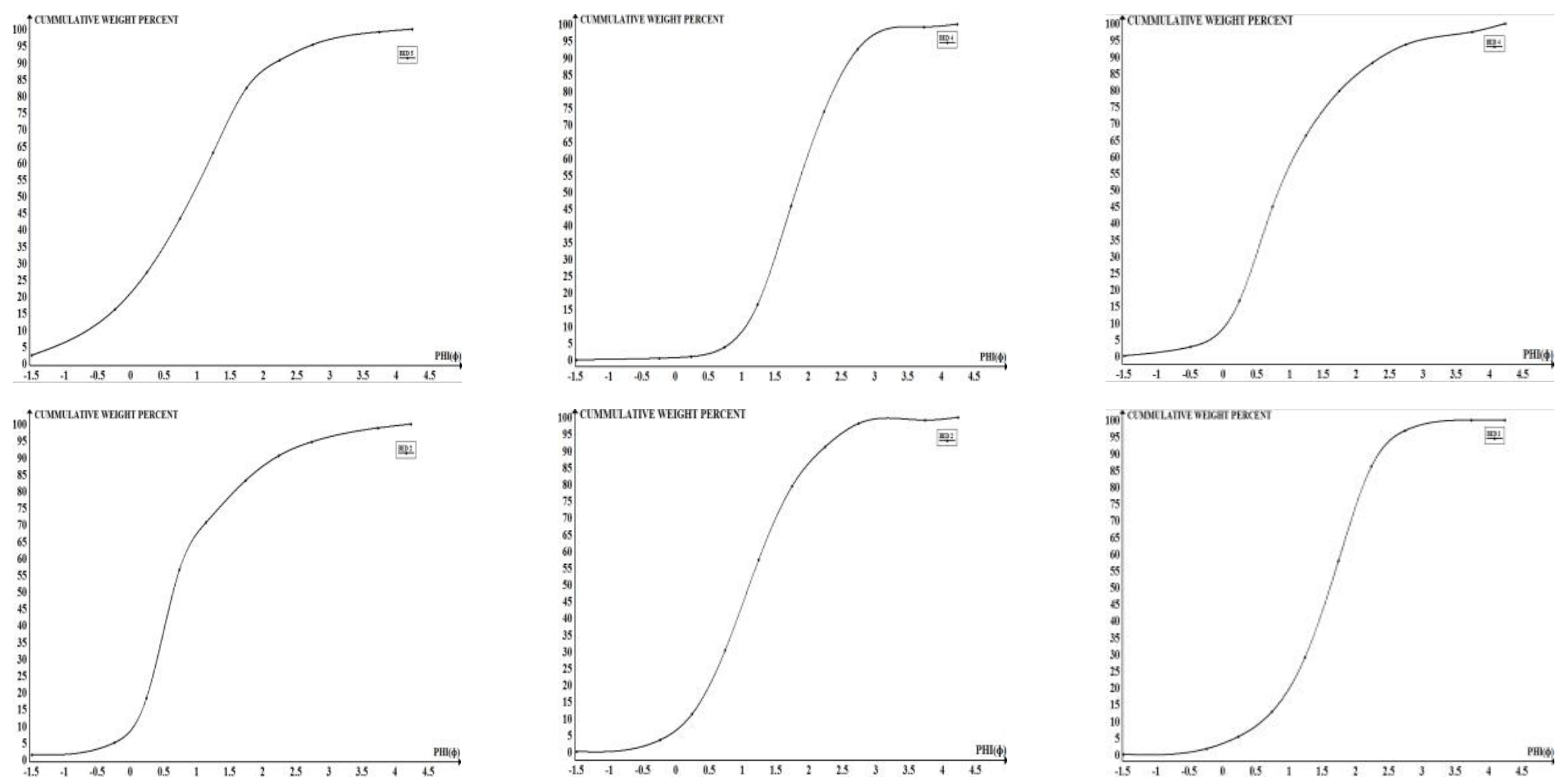

Fig. 4. Graphical representation of percentiles from sieve analysist 


\subsection{Organic Geochemical Analysis}

\subsubsection{The organic matter richness of the shales}

The organic matter richness of source rock is usually determined using the total organic carbon content, which is the total amount of organic material (kerogen) present in the rock, expressed as a percentage by weight (TOC wt.\%).

The higher the TOC value the better the chance and potential for hydrocarbon generation. According to [14], the TOC values between 0.5 and $1.0 \%$ indicate a fair source generative potential, TOC values varying from 1.0 to $2.0 \%$ reflect a good generative potential whilst values between 2.0 and 4.0 refer to a very good generative potential, and rocks with TOC greater than $4.0 \%$ are considered to have excellent generative potential. The TOC values obtained in this work range from $0.17-1.42 \mathrm{wt}(\%)$, with a mean of $0.7 \pm 0.4$ wt. $(\%)$, indicating that the shale samples have non to good hydrocarbon generative potential (Fig. 5).

\subsubsection{Hydrocarbon generative potential}

The SOM of the samples ranges from 150 to $1350 \mathrm{ppm}$ with the average hydrocarbon generative potential of 500 ppm. [14], showed that source rock with SOM in the range of $0-500$ ppm has a poor potential for petroleum generation; between $500-1000$ ppm is fair ; 1000 2000 ppm is good; $2000-4000$ ppm is very good while those with values above $4000 \mathrm{ppm}$ have excellent petroleum potential. Therefore the shales have poor to excellent generative potential for oil and gas (Fig. 6).

\subsubsection{Transformation ratio (TR)}

The transformation ratio (TR) defined by SOM/TOC was used as a maturity index. It is a measure of the transformation of kerogen into hydrocarbon. [15], stated that TR values between

Table 4. Calculated permeability for the outcropping sandstone facies at Imiegba

\begin{tabular}{lllll}
\hline Sample intervals & Median(dm) & Sorting(ס) & Permeability(md) & Remark \\
\hline BED 1 & 2.0 & 0.29 & 393.72 & VERY GOOD \\
BED 3 & 1.9 & 1.14 & 444.17 & VERY GOOD \\
BED 5 & 2.24 & 1.67 & 724.85 & VERY GOOD \\
BED 6 & 1.6 & 1.91 & 623.40 & VERY GOOD \\
BED 7 & 2.14 & 0.78 & 307.18 & VERY GOOD \\
BED 13 & 1.66 & 0.97 & 554.61 & VERY GOOD \\
BED 15 & 2.59 & 0.26 & 361.89 & VERY GOOD \\
\hline
\end{tabular}

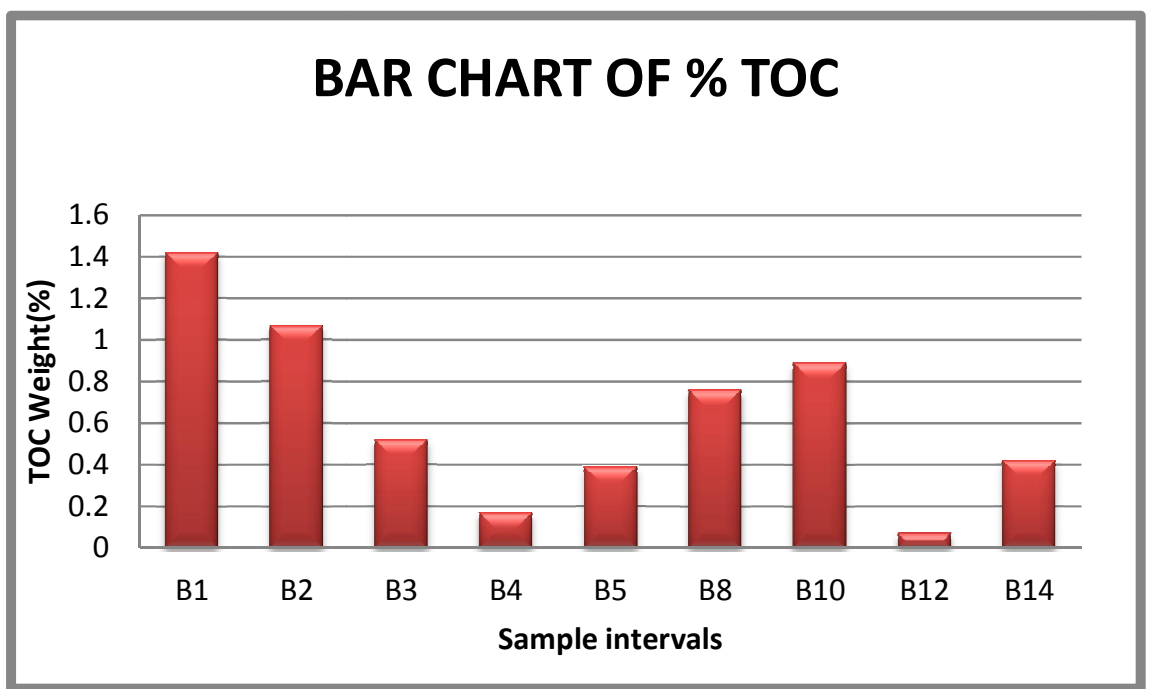

Fig. 5. Plot of TOC (Wt. \%) versus sample Intervals 
Table 5. Total organic carbon (TOC)

\begin{tabular}{llllll}
\hline S/N & Sample Id & TOC (\%) & SOM (PPM) & SOM (WT \%) & SOM/TOC \\
\hline 1 & IMIEGBA BED I & 1.42 & 11500 & 1.15 & 0.80 \\
2 & IMIEGBA BED 2 & 1.07 & 9500 & 0.95 & 0.88 \\
3 & IMIEGBA BED 3 & 0.52 & 4500 & 0.45 & 0.86 \\
4 & IMIEGBA BED 4 & 0.17 & 1500 & 0.15 & 0.88 \\
5 & IMIEGBA BED 5 & 0.39 & 2300 & 0.23 & 0.58 \\
6 & IMIEGBA BED 8 & 0.76 & 5900 & 0.59 & 0.77 \\
7 & IMIEGBA BED 10 & 0.89 & 7500 & 0.75 & 0.84 \\
8 & IMIEGBA BED 12 & 0.70 & 5900 & 0.59 & 0.84 \\
9 & IMIEGBA BED 14 & 0.42 & 2900 & 0.29 & 0.69 \\
\hline
\end{tabular}

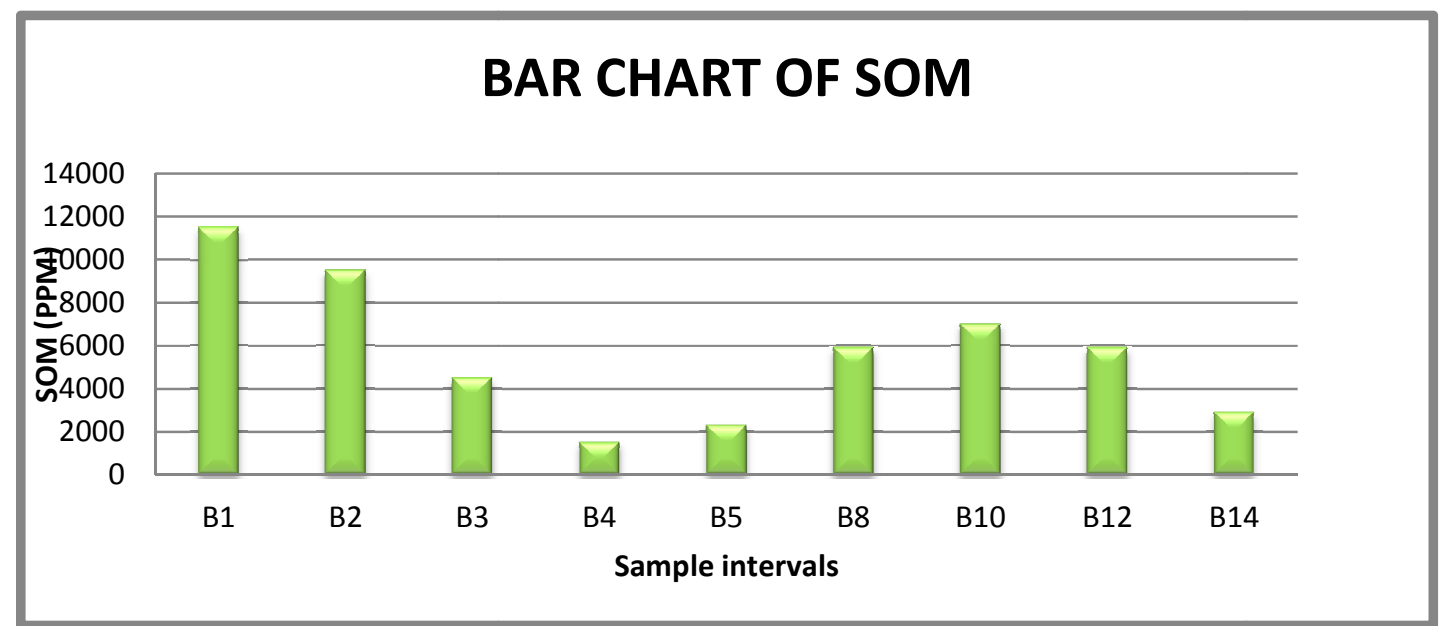

Fig. 6. Plot of SOM (ppm) versus sample beds

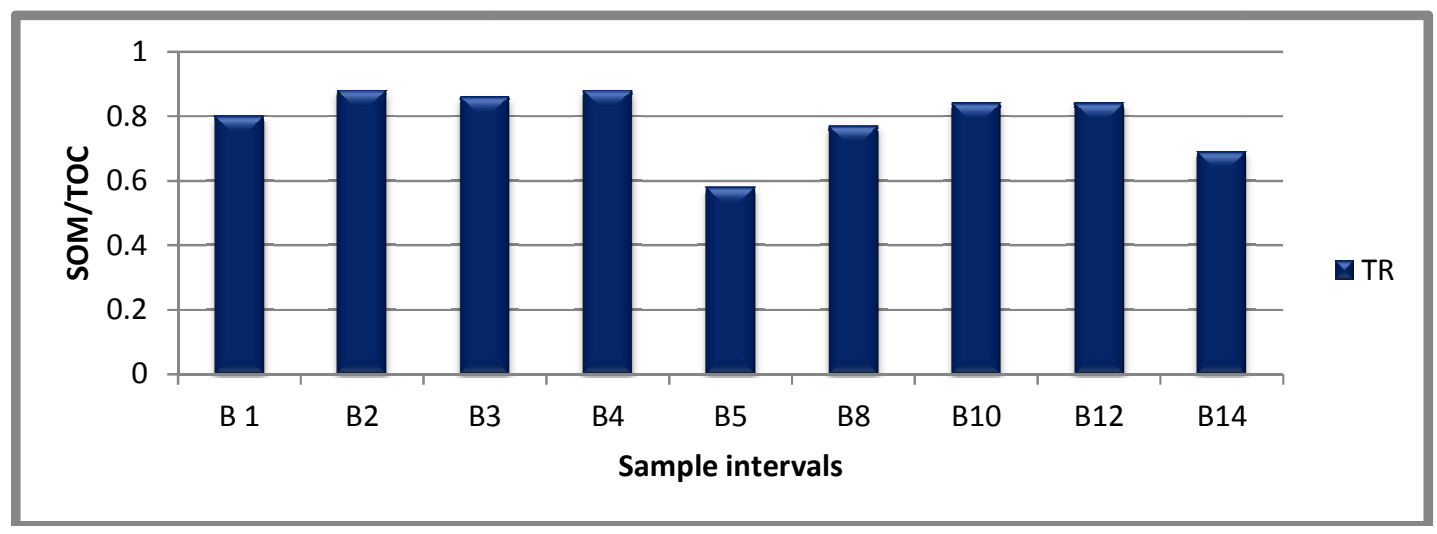

Fig. 7. Plot of transformation ratio (TR) versus sample intervals

0.002-0.016 indicate no hydrocarbon generation. The mean transformation ratio of $0.79 \pm 0.1$ was far above the threshold value required for hydrocarbon source generation, implying that the organic matter in the shales is mature and in adequate concentration for hydrocarbon generation (Fig. 7).

\section{SUMMARY AND CONCLUSION}

Based on sedimentological and field evidences, the main lithofacies identified from the study area are sandstone, shale and mudstone. The sandstones are fine to medium-grained and friable. The result of the textural analyses 
showed that the sandstones are sub-rounded, moderately to poorly sorted, strongly coarsely skewed and mesokurtic. The calculated permeability values ranging from 307.18-724.85 Md showed that they possess good permeability. Based on the high permeability values of the sands, the sandstones were inferred as good to excellent potentials for fluid transmission consequently, a good reservoir for hydrocarbon.

The TOC values ranges from $0.17-1.42$ wt (\%) with most of the samples above the threshold of 0.5 wt\% with SOM greater than $500 \mathrm{ppm}$ indicating that the shales have poor to good organic matter quantity and in adequate concentration for petroleum generation. In Conclusion, the result of the various analyses carried out showed that the sandstones are moderately to poorly sorted with high permeability, indicating a good reservoir quality for the sandstone, while the geochemical parameters showed that hydrocarbon generation potential of the shale samples is fair, therefore can source hydrocarbon.

\section{COMPETING INTERESTS}

Authors have declared that no competing interests exist.

\section{REFERENCES}

1. Nwajide CS, Reijers TJ. Sequence architecture in outcrops. Examples from the Anambra Basin, Nigeria. NAPE Bull. 1996;11:23-33.

2. Whiteman AJ. Nigeria. its petroleum geology, resources and potential. Graham and Trotman, London. 1982;399.

3. Murat C. Stratigraphy and paleogeography of the cretaceous and lower Tertiary in South-Eastern Nigeria. In: Dessauvagie TFJ, Whiteman A.J (eds), African Geology; 1972.
4. Burke KC. The African plate. South African Journal of Geology. 1996;99:341-409.

5. Benkhelil J. The origin and evolution of the Cretaceous Benue Trough, Nigeria. J Afr Earth Sci. 1989;8:251-282.

6. Reyment RA. Aspects of the geology of Nigeria. University of Ibadan Press, Ibadan Nigeria. 1965;145.

7. Nwajide CS. Cretaceous sedimentation and palaeogeography of the Central Benue Trough. In: Ofoegbu C.O (ed.), The Benue Trough, Structure and Evolution, Friedr. Vieweg and Sohn, Braunchweig/ Wiesbaden. 1990;19-38.

8. Obi GC. Depositional model for the Campano- Maastrichtian Anambra Basin Southern Nigeria. 2000;291.

9. Peters KE. Guidelines for evaluating petroleum source rock using programmed analysis. The American Association of Petroleum Geologists Bulletin. 1986; 70:318-329.

10. Folk LR, Ward CW. Brazos River Bar: A study in the significance of grain size parameters. Journal of Sedimentary Petrology. 1957;27(10):3-26.

11. Moiola RJ, Wieser D. Textural parameters: An evaluation. Journal of Sedimentary Petrlogy. 1968;38:45-53.

12. Krumbrien WC, Monk GD. Permeability as a function of unconsolidated sand. $\mathrm{J}$ of Petroleum Technology. 1942;5:1-11.

13. Kammamn PJ, Ritzi RW, Dominic DF, Conrad CM. Porosity and permeability in sediment mixtures. Groundwater. 2007;45 (4):429-438.

14. Peters KE, Cassa MR. Applied source rock geochemistry in Magoon, L. B, and W. G. Dow, eds., The petroleum system-from source to trap: AAPG Memoir 60; 1994.

15. Deroo G, Herbins JP, Roucache J, Tissot B. Organic geochemistry of some cretaceous black shale from sites 367 and 368. ARPN Journal of Science and Technology. 1988;3(8).

(c) 2017 Asadu and Ibe; This is an Open Access article distributed under the terms of the Creative Commons Attribution License (http://creativecommons.org/licenses/by/4.0), which permits unrestricted use, distribution, and reproduction in any medium, provided the original work is properly cited. http://sciencedomain.org/review-history/19591 